\title{
AN INTELLIGENT TUTORING SYSTEM FOR LEARNING LISTENING TOEIC
}

\author{
Maria Asumpta Deny Kusumaningrum ${ }^{1}$, Dewanti Ratna Pertiwi ${ }^{2}$ \\ ${ }^{1}$ Teknik Penerbangan, Institut Teknologi Dirgantara Adisutjipto Yogyakarta, ${ }^{2}$ Teknik Mesin, \\ Institut Teknologi Dirgantara Adisutjipto Yogyakarta \\ Jl. Janti Blok R Lanud Adisutjipto, Banguntapan, Bantul, Yogyakarta \\ ${ }^{1}$ Email: mariadeny@itda.ac.id \\ ${ }^{2}$ Email: dewantiratna@itda.ac.id
}

\begin{abstract}
Nowadays, English proficiency to be one of the main requirements when someone continuous study and applies for a job. One of them is TOEIC (Test of English for International Communication). In SMK AAG Penerbangan Adisutjipto Yogyakarta, TOEIC is used to measure the students' English proficiency. Various job vacancy advertisements require the applicants to achieve the standard TOEIC score. Therefore, preparation for taking English proficiency is needed to equip the students ready in facing the TOEIC test. Artificial intelligence (AI) technology can help to improve the students' English proficiency. The use of AI becomes higher due to the advantages such as flexibility, accurateness, and direct feedback. This program applied AI technology to develop listening skill in TOEIC of the students in SMK AAG Penerbangan Adisutjipto Yogyakarta. The result from this community service is the students know the skills and strategies to do the listening skill in TOEIC test.
\end{abstract}

Keywords: TOEIC, VHS, listening skill

\begin{abstract}
ABSTRAK
Saat ini, kemampuan bahasa Inggris menjadi salah satu syarat utama seseorang melanjutkan studi dan melamar suatu pekerjaan. Salah satunya adalah TOEIC (Test of English for International Communication). Di SMK AAG Penerbangan Adisutjipto Yogyakarta, TOEIC digunakan untuk mengukur kemampuan berbahasa Inggris siswa. Berbagai lowongan kerja mengharuskan pelamar mencapai skor TOEIC tertentu. Oleh karena itu, persiapan berbahasa Inggris diperlukan untuk membekali siswa siap menghadapi tes TOEIC. Teknologi kecerdasan buatan (AI) dapat membantu meningkatkan kemampuan bahasa Inggris siswa. Penggunaan AI menjadi lebih banyak karena keunggulan seperti fleksibilitas, akurasi, dan umpan balik langsung. Pada program pengabdian masyarakat ini menerapkan teknologi AI untuk mengembangkan keterampilan listening dalam TOEIC pada siswa SMK AAG Penerbangan Adisutjipto Yogyakarta. Hasil dari pengabdian masyarakat ini adalah siswa mengetahui keterampilan dan mengerjakan listening dalam tes TOEIC.
\end{abstract}

Keywords: TOEIC, SMK, ketrampilan mendengar 


\section{INTRODUCTION}

In the current era of globalization, the existence of English is considered important because it is the language used in international communication. In Indonesia, although the English position is not as second language, English is a language foreigner first taught in formal schools starting from elementary school level to university. Therefore, it is important for Indonesian people to learn English. The purpose of language learning is to communicate both verbally and in writing with the language being studied. There are four skills that must be mastered when learning English, there are listening, speaking, reading and writing. These language skills are related between one another and also for achieving the goal of learning languages as well as learners ideally study language components, such as structure, vocabulary, pronunciation.

All of the high school levels also apply push their students to develop the English proficiency skills. However, the focus for senior high school is different between vocational high school. Hambali (2019) said that a vocational high school (VHS) is a type of educational institution which design to provide technical skills required to complete the tasks of a particular and specific job. It is a great way to gain job-ready skills that prepare the students for a fulfilling career. Compared to senior high school students who are usually more academic, vocational high school students are more job-focused. There are two types of VHS in terms of years accomplishment, namely three-year and four-year program (Soenarto, Amin, \& Kumaidi, 2017). They report that the four-year program is higher in quality due to the more attained skills and knowledge.

Preparing VHS students for facing English proficiency test is necessary to maximize the quality of the students to compete in the labor market (Suharno, 2020). In VHS, the English proficiency test used is TOEIC (Test of English for International Communication). TOEIC as quoted from PLTI is a proficiency test for English communication to people who is not English native speaker. This test measures the level of English language skills, especially the ability to understand the content oral and written texts, both implied and the express. This test is useful to find out someone's English language skills field of education and it is used as supporting professional performance.

A community service in the form of developing English proficiency skill especially in listening TOEIC was carried out in SMK Penerbangan AAG Adisutjipto. It is an aviation vocational high school with airframe powerplant, electrical avionics, aircraft electricity, light 
vehicle engineering, and aircraft machining concentrations. The technique promoted was artificial intelligence technology namely TOEIC LISTENING A REAL PRACTICE TEST application.

Based on the interview from the teachers and based on the investigation, TOEIC is really needed for SMK AAG Adisutjipto Yogyakarta students. They take TOEIC test at the end of the semester and they also use TOEIC score for their future career. The future career of the alumni of SMK Penerbangan AAG Adisutjipto are in international airline companies such as Garuda Maintenance Facility, Lion, etc. In terms of applying the job, they need to achieve the standard TOEIC score. SMK AAG Adisutjipto provides the extracurricular to help the students improving their TOEIC skills. However, still some of the students are less motivated to develop their English proficiency. The outcome of this project was able to improve the students' listening TOEIC skills by having artificial intelligence (AI) technology.

\section{METHOD}

Refer to the partner's problems, the community service will be conducted in terms of action research following the scheme of Kemmis and McTaggart (1988) as described in Burns (2010).

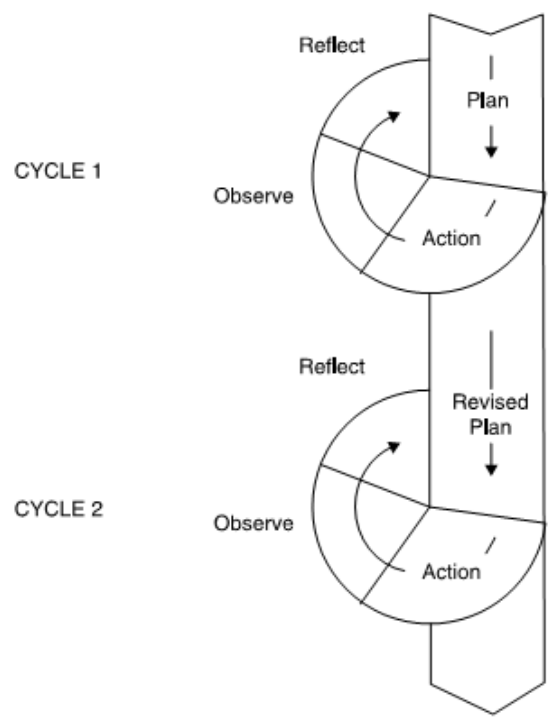

Figure 1. Cyclical AR model based on Kemmis and McTaggart (1988)

The procedures of conducting the service were on Figure 2: 


\section{Cycle 1}

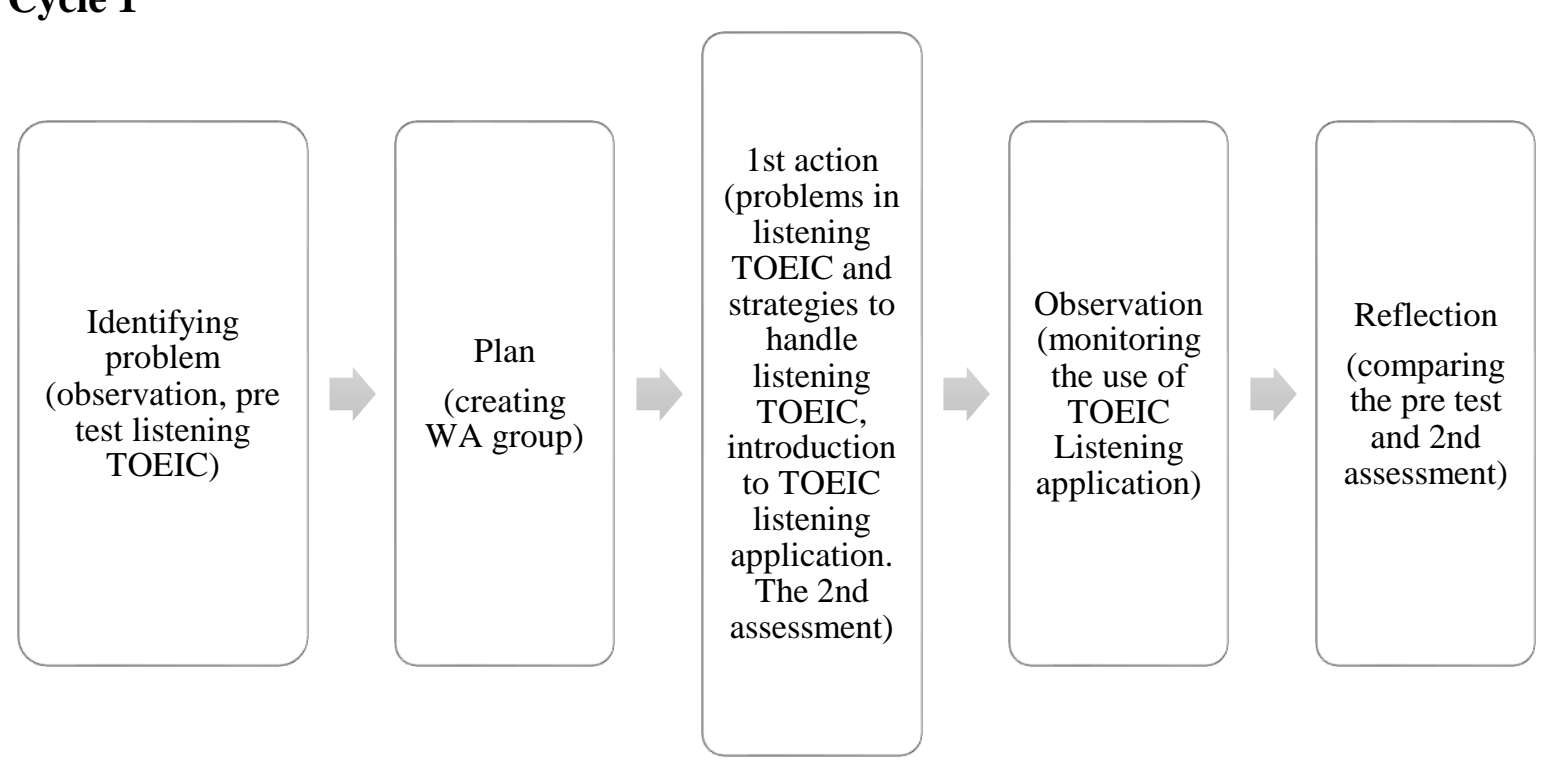

\section{Cycle 2}

\begin{tabular}{|c|c|c|c|}
\hline $\begin{array}{c}\text { Plan } \\
\text { (discussing the } \\
\text { 2nd cycle) }\end{array}$ & $\begin{array}{c}\text { 2nd action (giving } \\
\text { the 3rd } \\
\text { assessment) }\end{array}$ & $\begin{array}{l}\text { Observation } \\
\text { (monitoring the } \\
\text { use of TOEIC } \\
\text { Listening } \\
\text { application) }\end{array}$ & $\begin{array}{c}\text { Reflection } \\
\text { (comparing the } \\
\text { 2nd and the 3rd } \\
\text { assessment) }\end{array}$ \\
\hline
\end{tabular}

Figure 2. Community Service Procedures

The community service was conducted on January 2021 applied in the students of SMK Penerbangan AAG Adisutjipto (Komplek Lanud Adisutjipto, Jl. Janti, Karang Janbe, Maguwoharjo, Kec. Depok, Kabupaten Sleman, Daerah Istimewa Yogyakarta 55281). The name of the artificial intelligence is Listening for the TOEIC Test. It is available both in android and apple. This application only focuses on the listening section of TOEIC test. There are 4 parts consist in this application, which are picture description, question and responses, short conversation, and short talks. It is expected that by having this application and practicing effectively, the students can improve and develop their listening skills.

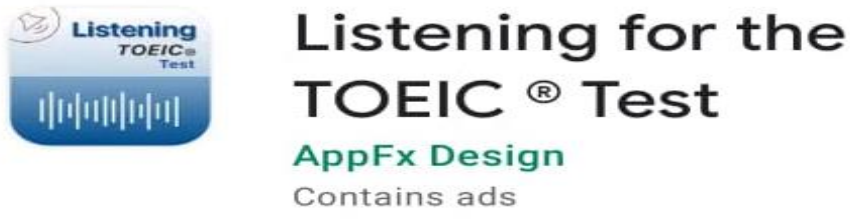

Figure 3. TOEIC Listening Application 


\section{RESULT AND DISCUSSION}

The treatment has been done into 2 cycles. To observe the starting state, to introduce the artificial intelligence and to perform the early assessments, the cycle 1 was done. It was convinced by cycle 2 which was focusing on the other evaluations after getting the enhancement from cycle 1 .

\section{Cycle 1}

\section{Identifying problem}

An observation was made to identify the problems by discussing how the condition of the students related to English comprehension skill especially listening for TOEIC skill. The observation was done with the vice head of academic affairs and the English teachers. The vice headmaster reported that some selected students have joined an English community to develop their English skills and prepare for an agenda that requires English skills someday. Students from all departments and grades follow this community. The students in this community have great English proficiency in general.

The English teachers said that in the Advanced TOEIC prediction test, only few students in this community achieved more than 800 marks. The teachers expected that after the community service, the students' listening ability will improve. They also informed that the teachers give some treatments to improve the students' English ability but they have never applied an application to support the learning TOEIC.

\section{Plan}

In order to organize more efficient communication, a follow-up phase was carried out. To accommodate the next steps, a WhatsApp room was built. The first action was webinar. This WhatsApp room was addressed to discuss the webinar and attended by the students, the English teachers and the community service lecturer. During the webinar, the lecturer also asked some questions to identify the participants related to TOEIC in listening part. The questions and the responses are as follows: 
Table 1. question 1

\begin{tabular}{lllll}
\hline No. & Pertanyaan & Mudah & Biasa & Sulit \\
\hline $1 \quad \begin{array}{l}\text { Bagaimana menurutmu soal TOEIC pada } \\
\text { bagian listening? }\end{array}$ & $41 \%$ & $17 \%$ & $42 \%$ \\
\hline
\end{tabular}

Table 2. question 2

\begin{tabular}{llll}
\hline No. & Pertanyaan & Ya & Tidak \\
\hline & $\begin{array}{l}\text { Apakah ada persiapan dahulu sebelum } \\
\text { menghadapi tes TOEIC terutama pada } \\
\text { bagian listening? }\end{array}$ & $35 \%$ \\
\hline
\end{tabular}

Table 3. question 3

\begin{tabular}{llllll}
\hline No. & Pertanyaan & Part 1 & Part 2 & Part 3 & Part 4 \\
\hline \multirow{3}{3}{3} & $\begin{array}{l}\text { Part manakah yang menurutmu } \\
\text { paling sulit untuk dikerjakan di }\end{array}$ & $18 \%$ & $12 \%$ & 0.29 & 0.41 \\
& TOEIC bagian listening? & & & & \\
\hline
\end{tabular}

Table 4. question 4

\begin{tabular}{llllll}
\hline No. & Pertanyaan & Part 1 & Part 2 & Part 3 & Part 4 \\
\hline 4 & $\begin{array}{l}\text { Part manakah yang menurutmu } \\
\text { paling mudah untuk dikerjakan di }\end{array}$ & $76 \%$ & $0 \%$ & 0.05 & 0.19 \\
& TOEIC bagian listening? & & & & \\
\hline
\end{tabular}

Table 5. question 5

\begin{tabular}{llll}
\hline No. & Pertanyaan & Ya & Tidak \\
\hline 5 & $\begin{array}{l}\text { Sudah adakah upaya untuk meningkatkan } \\
\text { kemampuan TOEIC terutama di bagian } \\
\text { listening? }\end{array}$ & $60 \%$ & $40 \%$ \\
\hline
\end{tabular}

After the webinar, the lecturer also posted the 1st assessment by asking students to do the simplified TOEIC listening using Edmodo, which are part 1/picture description (5 questions), part 2/questions and responses (15 questions), part 3/short conversation (15 questions), part 4/short talk (15 questions). 
$\leftarrow \rightarrow$ C new.edmodo.com/library/folders/1036183715-Introductory\%20TOEIC

:\#: Apps M Gmail - YouTube



Figure 3. Picture Description

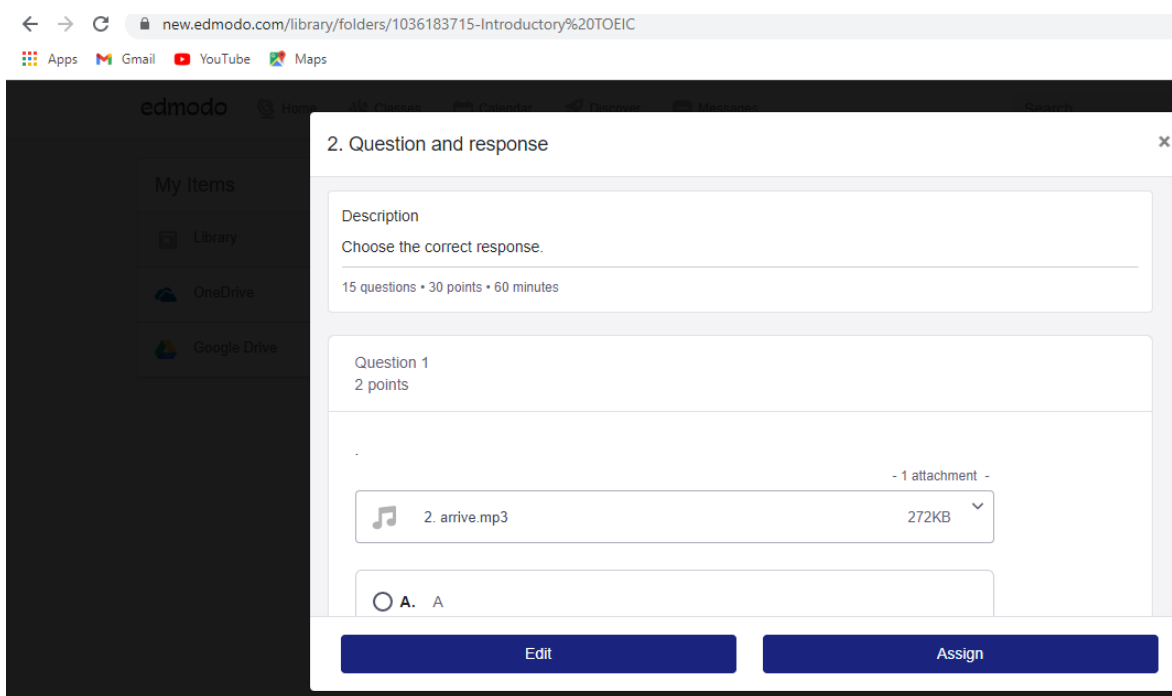

Figure 4. Questions and Responses 


\section{Jurnal Berdaya Mandiri}

Vol. 3 No. 1 Tahun 2021

E-ISSN: 2685-8398

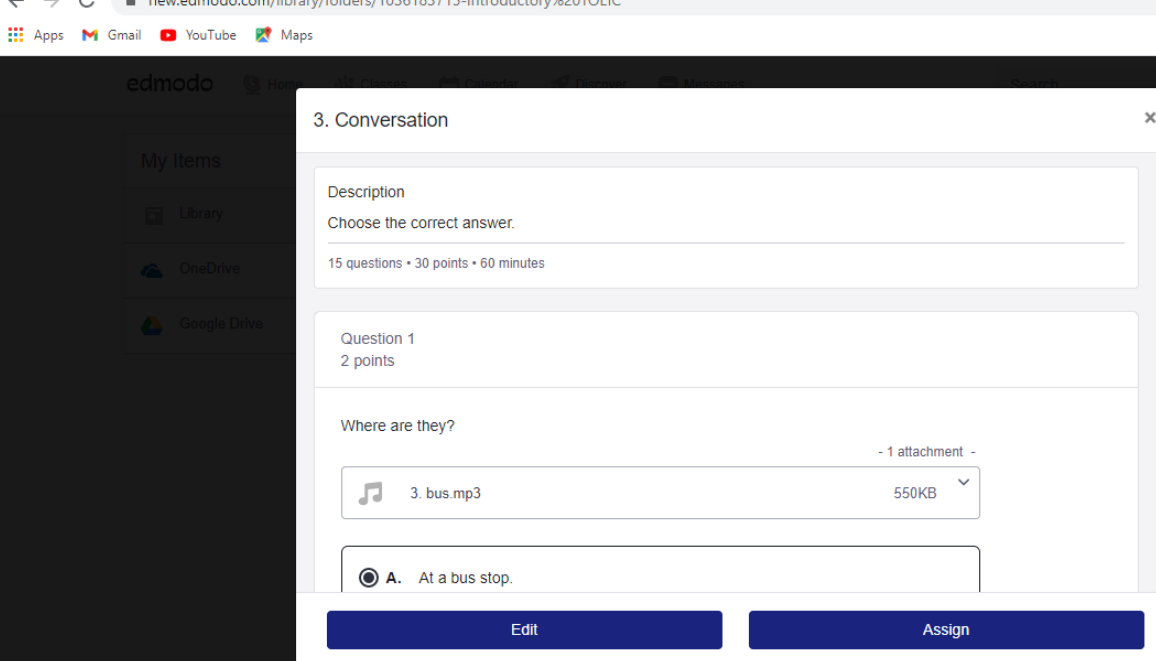

Figure 5. Short Conversation

$\leftarrow \rightarrow C \quad$ \& new.edmodo.com/library/folders/1036183715-Introductory\%20TOEIC

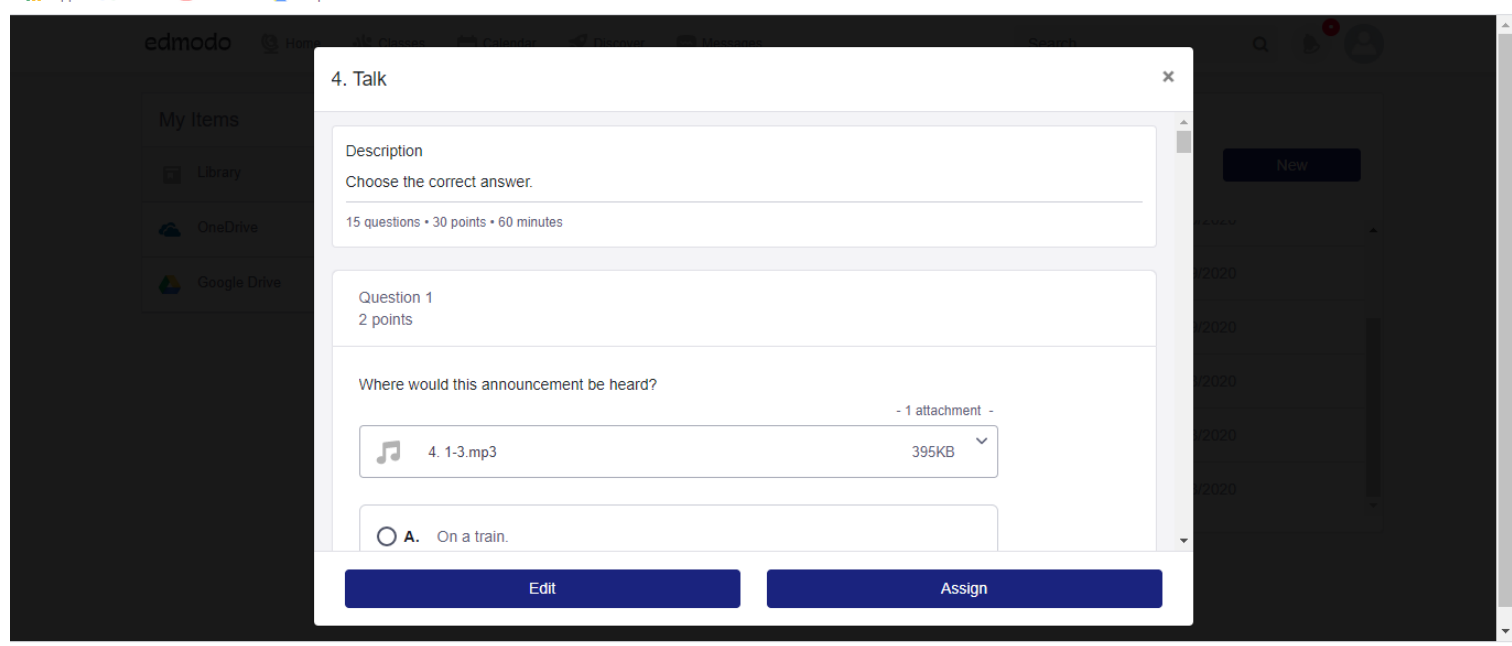

물 EC AP 2019 A.CSV

Show all $x$

* $\mathrm{a}$ ( 9 w

Figure 6. Short Talks 
This figure is to describe the result for the $1^{\text {st }}$ assessment:

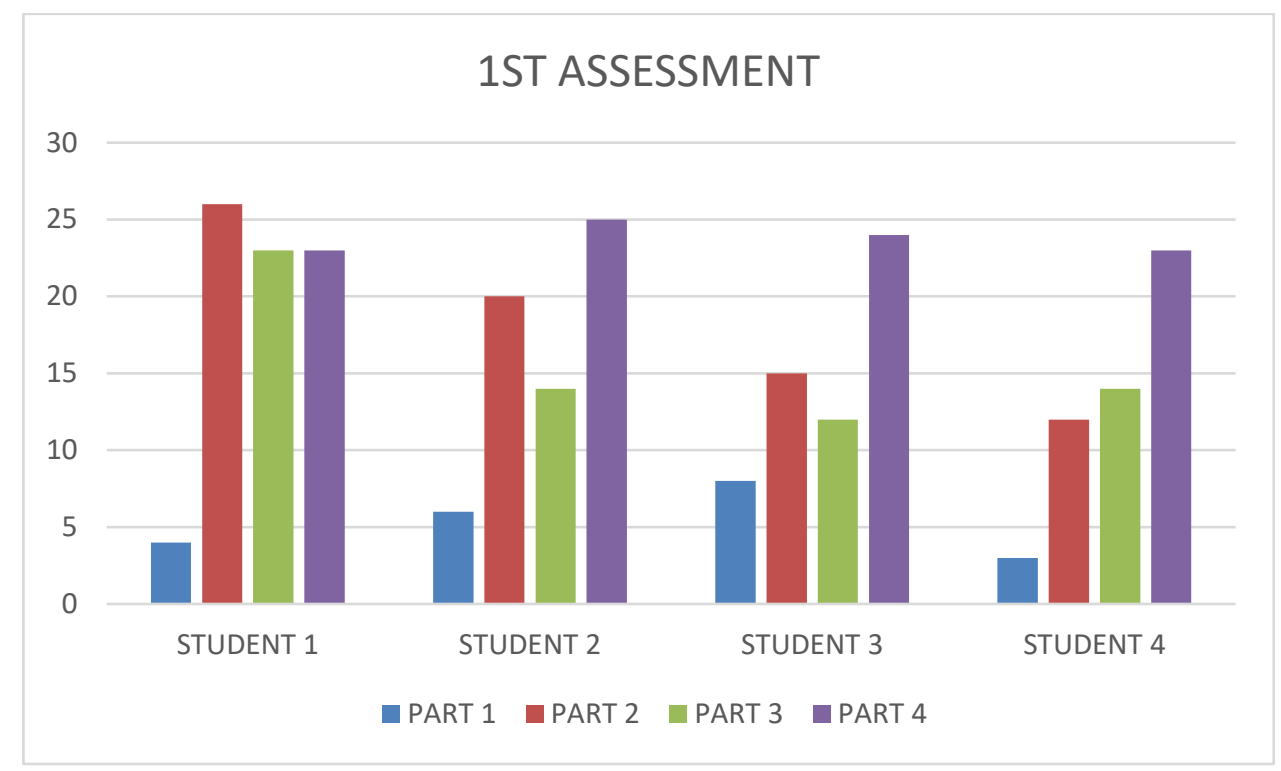

Figure 7. $1^{\text {st }}$ assessment of simplified TOEIC listening

\section{Action}

As it was still in the pandemic of Covid-19, the third action was performed in the webinar. The third step was the action to improve the listening TOEIC skill. This step, the lecturer introduced an artificial intelligent technology used to support the students learning TOEIC in listening part. The webinar was recorded and uploaded in YouTube with this link https://youtu.be/47xUirPVdCc. 


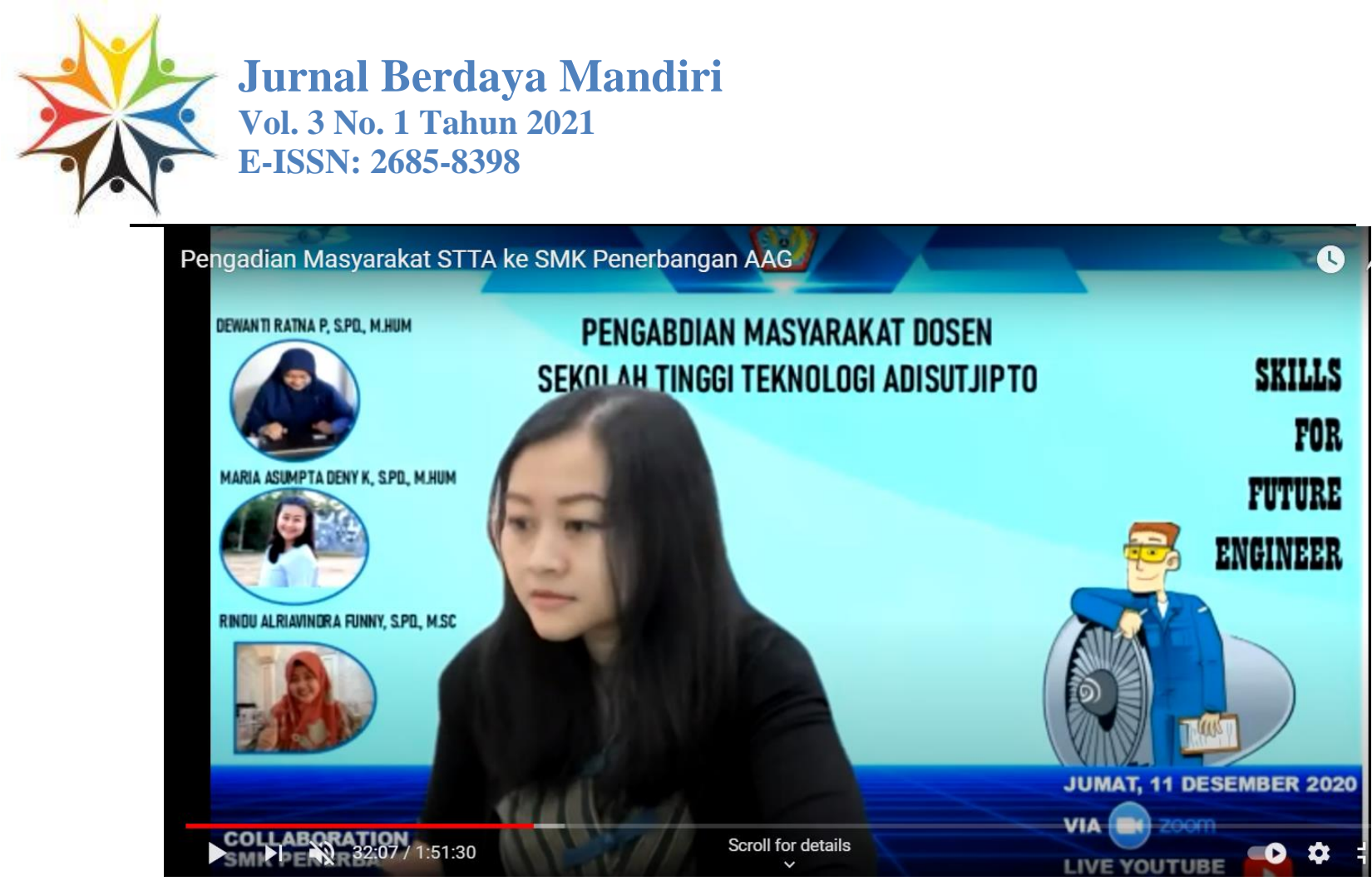

Figure 8. YouTube screen

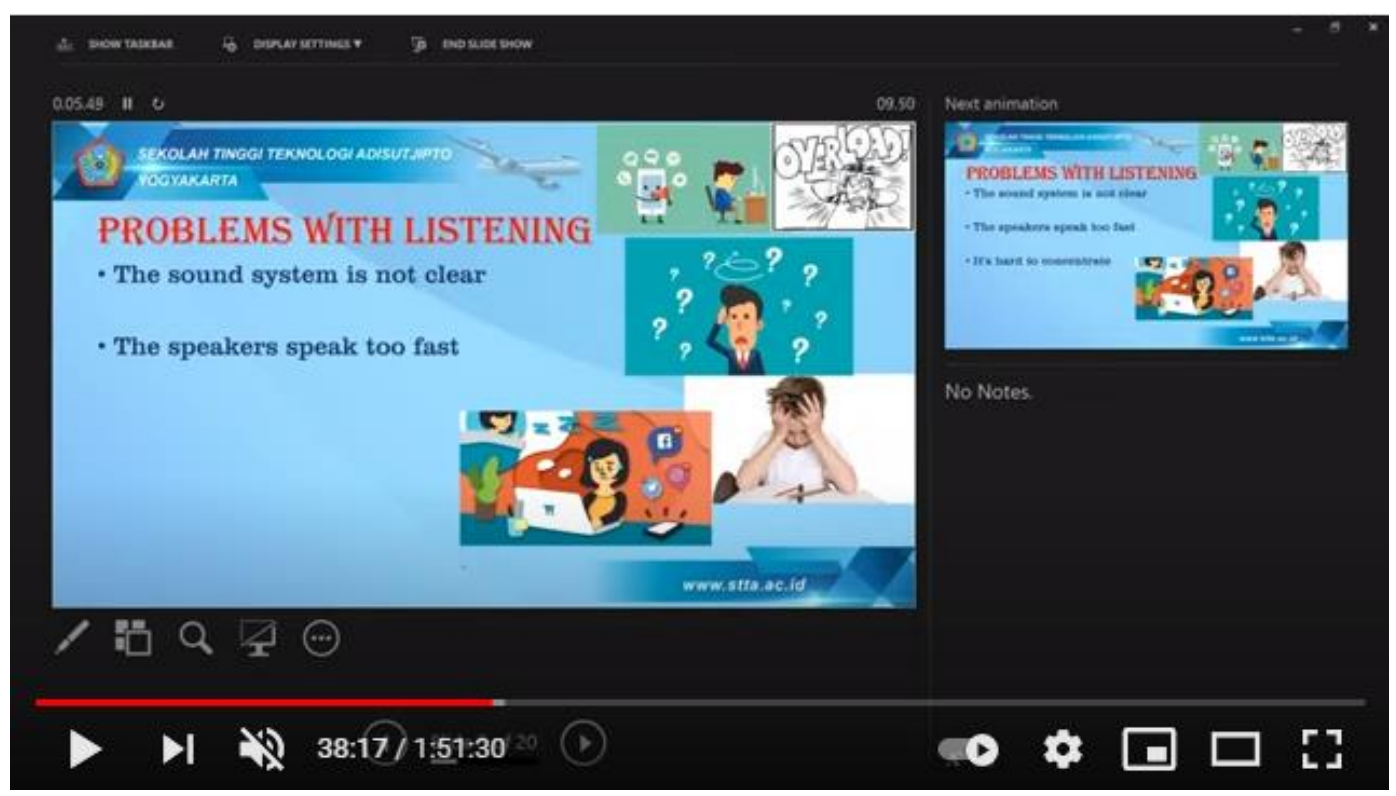

Figure 9. Power Point

After doing the need analysis and surveys of the applications, listening for the TOEIC test application is the best choice to be applied for students. This application gives the real TOEIC listening practice which is completed from picture description part, questions and responses part, short conversation part and short talk part. This application also provides the feedback for each question. 


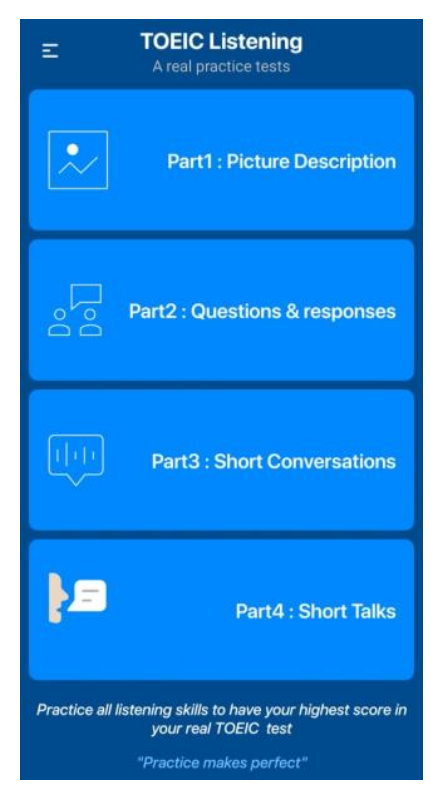

Figure 10. Home



Figure 11. Part 1 (picture description) and the feedback

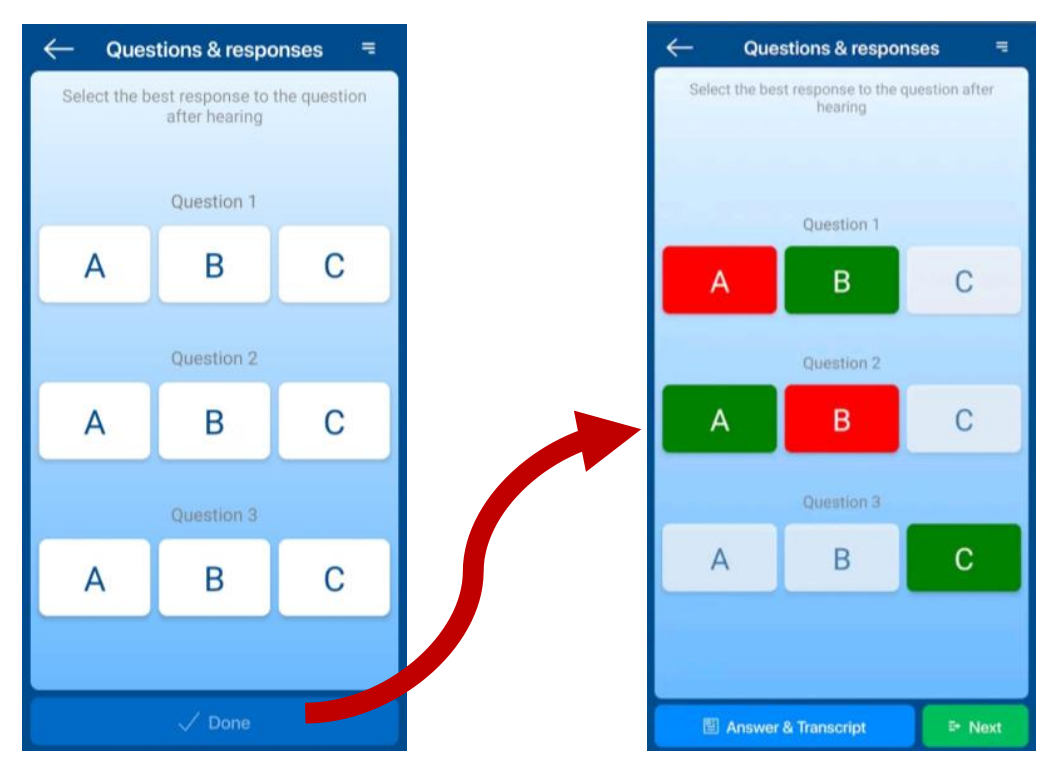

Figure 12. Part 2 (questions and responses) and the feedback 




\section{Jurnal Berdaya Mandiri}

Vol. 3 No. 1 Tahun 2021

E-ISSN: 2685-8398

$\begin{aligned} & \text { Short Conversations } \\ & \text { Select the best response to the question } \\ & \text { after hearing a short conversation }\end{aligned}$
1). What are the speakers mainly
discussing?
$\begin{array}{ll}\text { A } \text { (A) The stock market } & \text { Short Conversations } \\ \text { B (B) Bond funds } & \text { 1). What does the woman want to do? } \\ \text { (C) (C) Certificates of Deposit } & \text { (A) Pay taxes } \\ \text { (D) (D) Interest rates } & \text { (C) Find a job } \\ \text { 2). How does the man feel about the } & \text { (D) Answer questions } \\ \text { stock market? } & \text { (A) Accountant } \\ \text { A (A) Confident } & \text { (B) Receptionist } \\ \text { (B) (B) Despondent } & \text { (C) Lawyer } \\ \text { (C) (C) Optimistic } & \text { (D) (D) Professor } \\ \end{array}$

Figure 13. Part 3 (short conversations) and the feedback

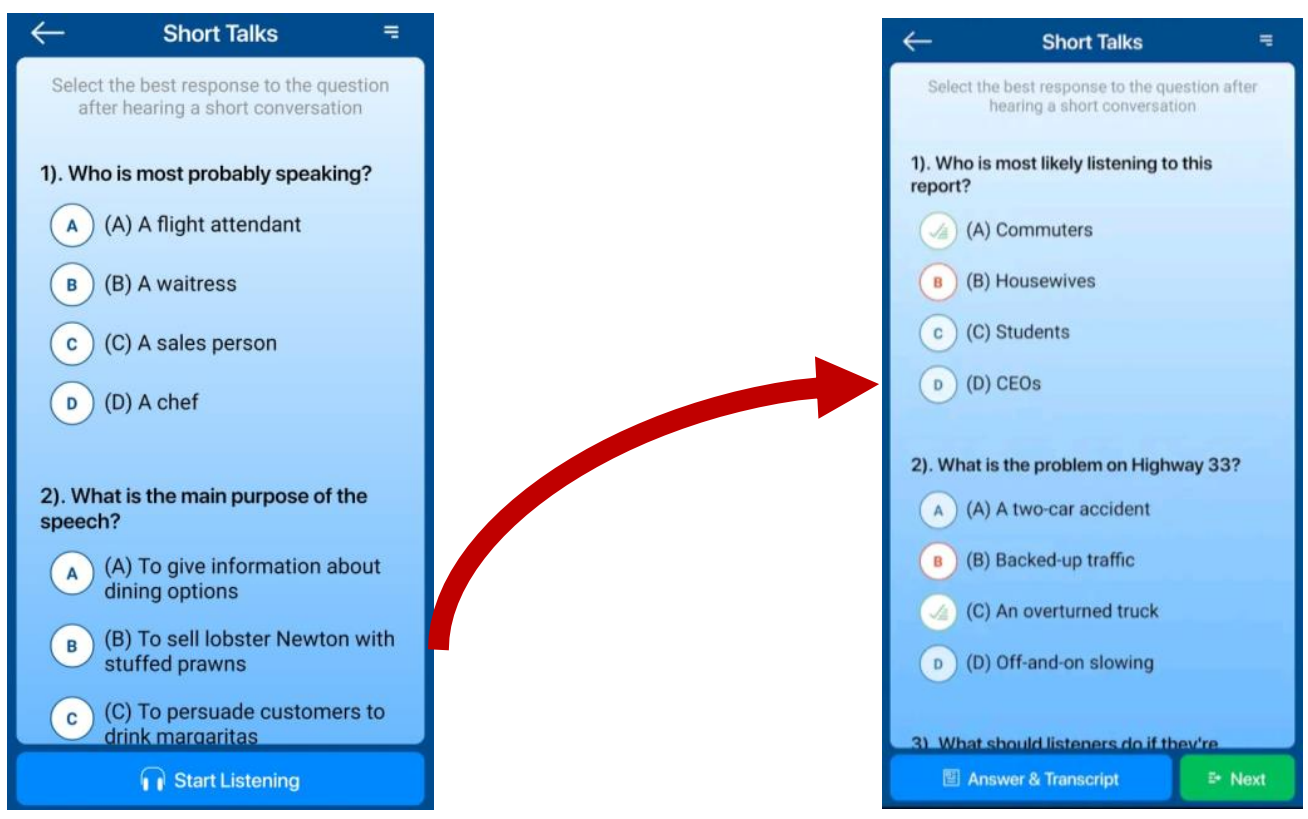

Figure 14. Part 4 (short talks) and the feedback

\section{Observation}

After the webinar, the lecturer had intensive communication with the students by WhatsApp room. It was done to monitor the students whether they faced the obstacles when running the application and doing the task or not. Then, the $2^{\text {nd }}$ assessment was done to check whether they did the improvement or not. The following is the result for the $2^{\text {nd }}$ assessment: 


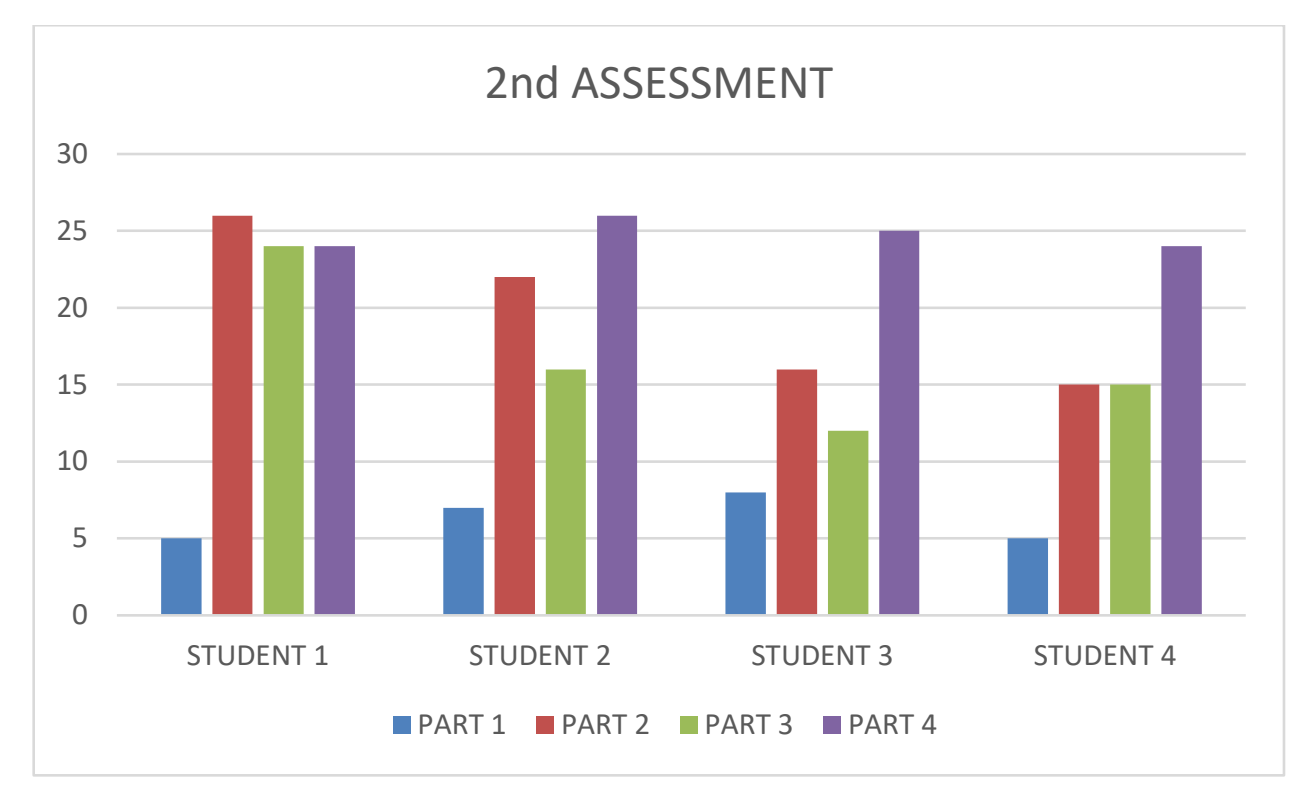

Figure 15. $2^{\text {nd }}$ assessment after the treatment

\section{Reflection}

It was important to compare the $1^{\text {st }}$ and $2^{\text {nd }}$ TOEIC assessment to see how much change occurred after doing the treatment. Part 1, part 3, and part 4 increased a little with an average mark of 1 . In addition, part 2 increased 1,5 average mark. Although there is no significant improvement, the students still make the progress.

\section{Cycle 2}

\section{Plan}

In an action research study, the result of the first cycle should be convinced by the following cycles for at least once. To begin Cycle 2, planning was conducted by discussing the next action. In this case, sharing and discussing about the obstacles faced when dealing with listening was carried out. The lecturer also gave some tips and strategies to handle listening TOEIC. In addition, the students still practiced the test using artificial intelligence technology. After that, the $3^{\text {rd }}$ assessment was done followed by reflection for the whole assessments.

\section{Action}

The discussion was delivered in WhatsApp room. Questions and answers session was closer, more natural, and more intensive. Some strategies were shared how to handle listening test especially in TOEIC test. Some students also discussed the questions from $1^{\text {st }}$ 


\section{Jurnal Berdaya Mandiri}

Vol. 3 No. 1 Tahun 2021

E-ISSN: 2685-8398

and $2^{\text {nd }}$ assessment. They were eager to know the correct answer and the explanation. The students also shared some problems that were found in using AI technology. This stage, lecturer also interviewed the participants' perception in using AI technology. They felt AI was interesting and helpful. They can bring everywhere and every time thus they can learn anytime.

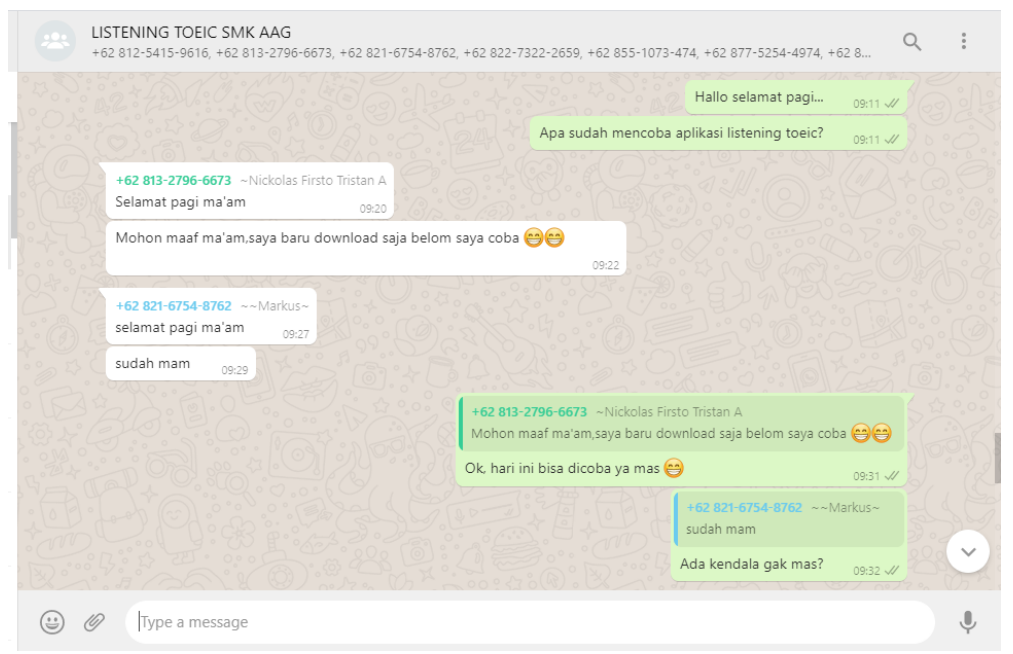

Figure 16. WhatsApp room

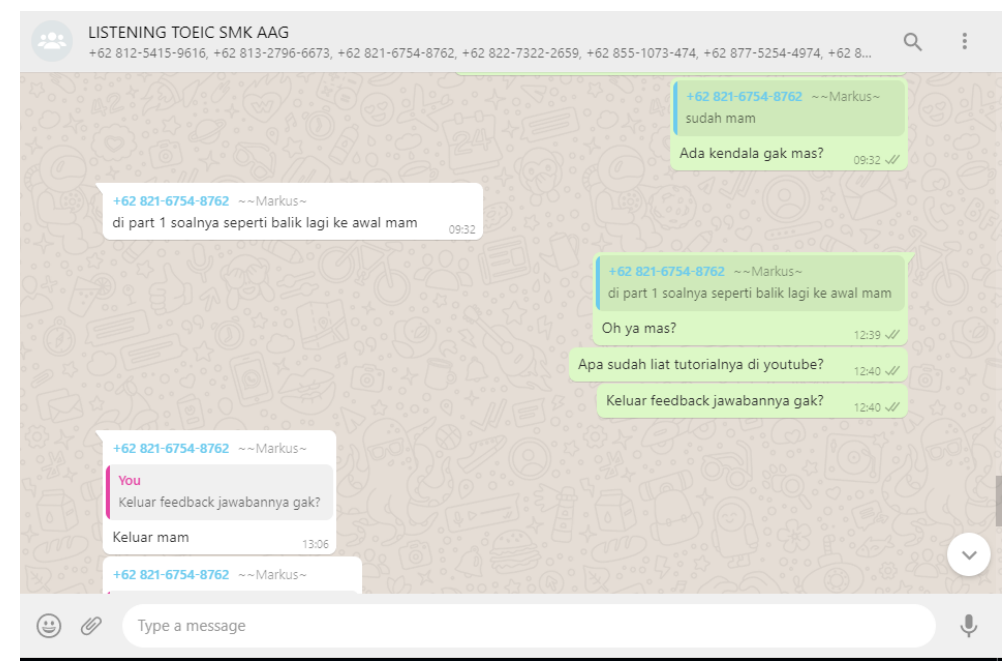

Figure 17. WhatsApp room

\section{Observation}

Observing the following improvement was carried out in the $3^{\text {rd }}$ assessment. Part 1 about picture description got the highest improvement among the other parts. The students were able to recognize the picture and able to interpret into the sentence. The students also 
improved their ability when dealing with part 2 and part 3 . However, the students decreased the score when dealing with part 4 . They said that they couldn't remember what the speaker said. Some of them said that they missed the information. Another said that they did not know the vocabulary.

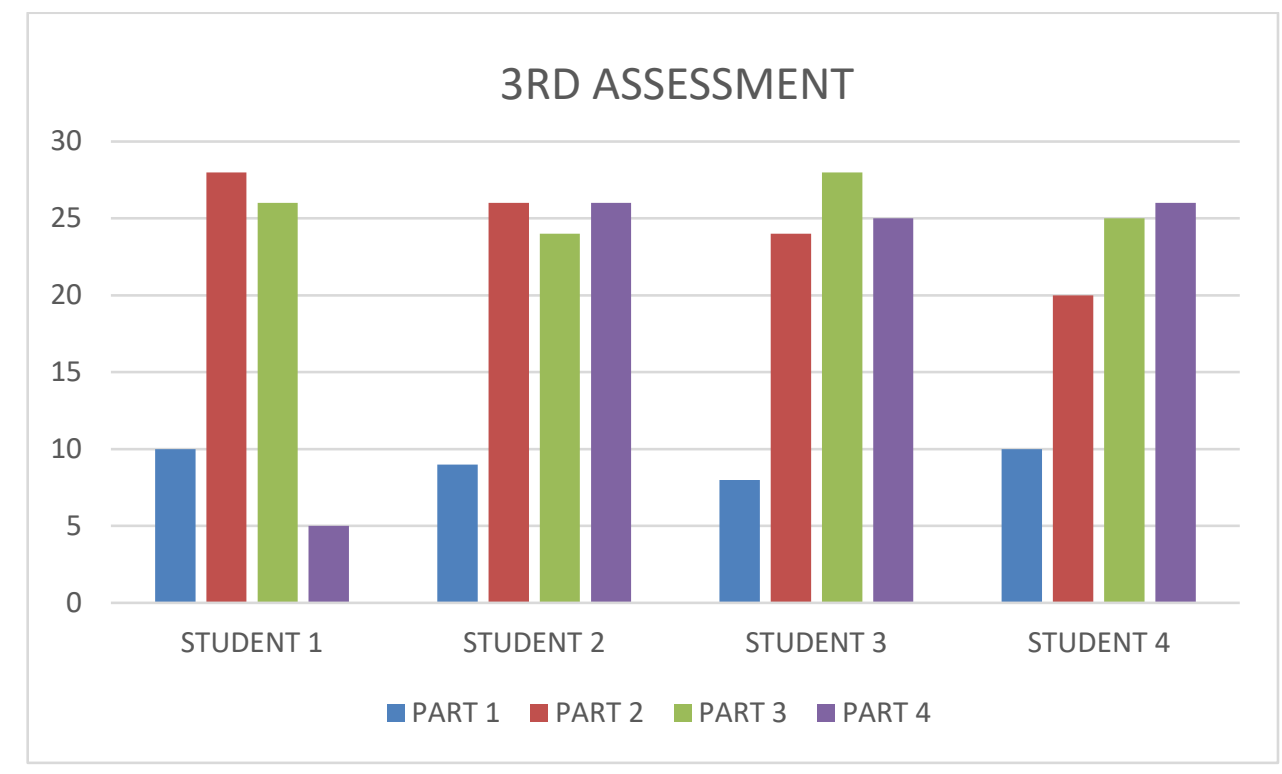

Figure 18. $3^{\text {rd }}$ assessment after the evaluation and the tratment

\section{Reflection}

Reflecting the three assessments, part 1 for picture description raised a lot from $1^{\text {st }}$ assessment, $2^{\text {nd }}$ assessment and the $3^{\text {rd }}$ assessment. Part 2 for questions and responses also got the improvement from the $1^{\text {st }}$ assessment, the $2^{\text {nd }}$ assessment and the $3^{\text {rd }}$ assessment. Part 3 for short conversation raised a little from the $1^{\text {st }}$ assessment to the $2^{\text {nd }}$ assessment but raised a lot from the $2^{\text {nd }}$ assessment to the $3^{\text {rd }}$ assessment. However, part 4 for short talks raised a little from $1^{\text {st }}$ assessment to the $2^{\text {nd }}$ assessment and decreased a little from $2^{\text {nd }}$ assessment to the $3^{\text {rd }}$ assessment. They said that they couldn't remember what the speaker said. Some of them said that they missed the information. Another said that they did not know the vocabulary.

\section{CONCLUSION}

The research concluded that the artificial intelligence (AI) technology was able to improve the students' listening TOEIC skills. The students' performance indicated positive 
improvement on the listening skills. The AI allowed the students to use and develop autonomously and flexibly to get the feedback.

\section{RECOMMENDATION}

For the following research, it is recommended to design more projects for other themes and involve more technologies. This project accommodated only some questions in each cycle. It is expected that the following research can accommodate the complete questions. The lecturers only guided the students to apply AI during 2 weeks. It is expected that the next project it can be done longer.

\section{REFERENCES}

Abu Ghali, M., Abu Ayyad, A., Abu-Naser, S., \& Abu Laban, M. (2018). An Intelligent Tutoring System for Teaching English Grammar. International Journal of Academic Engineering Research (IJAER), 2(2), 1-6.

Burns, A. (2010). Doing Action Research in English Language Teaching: A Guide For Practitioners. New York: Routledge.

Hambali, I. M. (2019). Examining The Relevance of Indonesian Vocational High School Career Outcomes to The Labor Market IM Hambali 1. 10(1), 133-155.

https://www.plti.co.id/produk-jasa/toep-teflin

http://sobatbaru.blogspot.co.id/2010/03/teori-toeic.html

Soenarto; Amin, M. M. . K. (2017). An evaluation of vocational high schools in Indonesia: A. 3(2), 106-113.

Suharno; Pambudi, N. A.; Harjanto, B. (2020). Vocational education in Indonesia: History, development, opportunities, and challenges. Children and Youth Services Review, 115(May), 105092. https://doi.org/10.1016/j.childyouth.2020.105092 